Tarbawi: Jurnal Ilmu Pendidikan p-ISSN:1858-1080 | e-ISSN: 2615-6547 Vol. 17, No. 1, June 2021, 65-72

\title{
The Effect of Emotional Intelligence on Students' Islamic Education Learning Outcomes
}

\author{
Aprianda \\ Sekolah Indonesia Johor Bahru \\ apriandasijb@gmail.com
}

\begin{abstract}
This research is motivated by the importance of student success in learning that is measured through learning outcomes. The reality shows that student learning outcomes in Islamic Education subjects are still low. Learning outcomes can be influenced by several factors, one of which is emotional intelligence. This study aims to determine the effect of emotional intelligence on student learning outcomes in Islamic Education subjects. This research is a quantitative approach by survey method. The population in this study was 40 students of the fifth grade at Sekolah Indonesia Johor Bahru, Malaysia. The total sampling technique selected that. The instrument in this research consisted of an emotional intelligence questionnaire and a learning outcome test. The data were analyzed using a simple linear regression test. Based on data analysis, it was found that emotional intelligence has a significant effect on student learning outcomes in Islamic Education subjects. Therefore, emotional intelligence needs to be honed from an early age because emotional intelligence is one of the axes of individual success in various aspects of life.
\end{abstract}

Keywords: Emotional Intelligence, Islamic Education, Learning Outcomes

\section{INTRODUCTION}

Education is a conscious and planned effort in developing one's potential to gain knowledge about religion, skills, intelligence, personality, and noble character, which will later be helpful for life. It shows that education is a vital aspect of life. Formal education aims to prepare students to become subjects who increasingly play a role in displaying their substantial, creative, independent, and professional advantages in their respective fields, one of which is Islamic education.

The existence of Islamic Education is very urgent in the national education system. It can be seen in the description of the national education goals. Achieving the goals of religious education means that it will be part of realizing national education goals. Furthermore, the implementation of religious education must be reflected and co-occur in experience, treatment, and examples in life and exercises and understandings about the teachings of religion itself.

Achieve the desired competence of Islamic Education in developing knowledge, attitudes, and religious skills following Islamic teachings. Islamic Education is an effort to foster and develop human potential to carry out their duties as servants of Allah to achieve the goal of happiness in the hereafter. Efforts to improve Islamic Education can be carried out through three educational pathways: formal, informal, and non-formal education. The implementation of Islamic Education is the root of the implementation of national education. In addition, one of the essential points that support the quality of education is the learning process. The learning process arranged systematically will affect the achievement of student learning objectives (Gafur, 2012). In other words, good management of the learning process is expected to achieve learning success.

The success of student learning can be seen from their ability to master the subject matter, skills in completing tasks given by the teacher, and the learning outcomes achieved by 
students. The essence of learning outcomes is a change in individual behavior, including cognitive, affective, and psychomotor aspects (Sudjana, 2014). In other words, learning outcomes are abilities obtained by students after going through learning activities carried out by evaluation or assessment and are away or follow-up to measure the level of student mastery.

The reality in the field shows that many students do not reach the minimum completeness criteria in learning Islamic Education. It can be seen from the scores of the midsemester examinations for Islamic Education for fifth-grade students at Sekolah Indonesia Johor Bahru. There were 13 out of 20 students or $65 \%$ of students who did not reach the minimum completeness criteria. In comparison, students who reach the minimum completeness criteria are only seven people or $35 \%$. This data shows that the learning outcomes of students' Islamic Education are still low. In learning, students tend to be passive and only receive information or explanations from the teacher.

Several factors can affect student learning outcomes, namely internal factors and external factors. Internal factors come from within students, such as motivation, emotional intelligence, attitudes, self-confidence, and creative thinking. In contrast, external factors come from outside students, such as facilities and infrastructure, environment, teachers, and teaching methods. The two factors above support each other, but internal factors are more dominant in student success.

According to Goleman (2015), intellectual quotient (IQ) only contributes 20\% to the factors determining success in life, while other factors contribute $80 \%$. Intellectual factors as cognitive intelligence are not the only factors of intelligence that affect learning achievement but are also influenced by other intelligence factors, namely other bits of intelligence that play a significant role, namely emotional intelligence (EI). Social and emotional skills will play an increasingly important role in achieving personal and professional success than intellectual abilities. Having a high emotional intelligence is very important in success compared to a high IQ as measured by standardized verbal and non-verbal cognitive tests. Emotional intelligence is abilities such as motivating ourselves and enduring frustration; controlling impulses and not exaggerating pleasure; regulating the mood, and keeping stress from crippling the ability to think; empathize, and pray (Goleman, 2015). Thus, emotional intelligence is a person's mental ability to recognize, understand, and manage his emotions effectively as a source of energy so that emotional expression can be done in a way and at the right time.

Through emotional intelligence, a student can manage his feelings, motivate himself, be strong in the face of frustration, control impulses and delay momentary gratification, set a reactive mood, and be able to empathize and cooperate with others. This intelligence supports a student in achieving his goals and ideals. Learning that is only centered on Intellectual Quotient without balancing the emotional side will result in a generation that is easily discouraged, depressed, so that many students are less aware of their duties as a student will result in a lack of motivation to learn and find it difficult to concentrate, so students will find it difficult to understand a lesson (Kurnia \& Wahono, 2021).

Based on the results of observations, it was found that many student participants did not have emotional skills, emotional skills in the sense that students were unable to control themselves, such as being indifferent, and their enthusiasm for learning was still low. Therefore, emotional intelligence has a significant role in the educational environment, both formal and non-formal educators, in achieving the personal success of students. So emotional intelligence in students should be a particular concern for educators in the learning process. According to Daud's research, learning outcomes are influenced by emotional intelligence (Daud, 2012). The results showed that the higher the emotional intelligence, the higher the learning outcomes achieved by students.

Conversely, low emotional intelligence corresponds to low learning outcomes. The existence of high emotional intelligence encourages students to be more able to achieve. Learning achievement will be good if formed and obtained from IQ and EI that function simultaneously in their lives. 
Good emotional intelligence is one of the determinants of the formation of students' personalities. All emotions are an urge to act (Goleman, 2015). So various kinds of emotions encourage individuals to respond or behave towards the stimulus they receive. Children who have better emotional intelligence can regulate their emotions and put themselves in various unexpected situations. With emotional intelligence, a person can know and respond to their feelings, so they are more likely to succeed in life because they have the motivation to achieve. Emotional intelligence has a dual role, namely influencing intrapersonal effectiveness such as motivation and self-regulation and interpersonal skills such as cooperation (Alvarez et al., 2020).

Low emotional intelligence will be difficult to focus (concentration) during the teaching and learning process, causing low student achievement. So emotional intelligence in students should be a particular concern for teachers in the learning process. The students who have good emotional intelligence can control themselves in the learning process. Positive emotions can function as an energy generator, as an automatic response to someone's critical moment, as a person's motivation to achieve what he dreams of, as a person's generator from adversity. From the information above, emotions can trigger high creativity, good collaboration with all themes, transformation or change in one's perspective, and be optimal in learning (Dewi, 2020). Emotional intelligence has a significant role in determining a person's success, especially in achieving learning achievement (Purnaningtyas et al., 2010). Several previous studies have also shown an influence of emotional intelligence on learning outcomes in mathematics, economics, and social science subjects.

Research conducted by Rahmawati et al. states that emotional intelligence significantly affects student learning outcomes in class XI IPS SMA Negeri 1 Prajekan, Bondowoso Regency, 2016/2017 academic year. With an influence of 36.65\% (Rahmawati et al., 2017). In addition, research conducted by Sulastri et al. shows that emotional intelligence also significantly influences students' mathematics learning achievement by $11.8 \%$ (Sulastri et al., 2021). Furthermore, in the research of Febrianti and Rachmawati, the results also showed that there was an influence of emotional intelligence on students' economic learning outcomes (Febrianti \& Rachmawati, 2018). The similarity between this research and the other research is that they both examine the effect of emotional intelligence on learning outcomes. The difference is in the subjects studied.

Seeing the importance of the role of emotional intelligence or Emotional Intelligence (EI) on learning outcomes, an in-depth study is needed about the influence of emotional intelligence on student learning outcomes in Islamic Education subjects. This study aims to determine the effect of emotional intelligence on student learning outcomes in Islamic Education subjects.

\section{METHOD}

This research is quantitative research with a survey method. The research was conducted at the Sekolah Indonesia Johor Bahru, Malaysia. The population in this research were all the fifth-grade students in the 2020/2021 academic year, totaling 40 students. The sampling technique used total sampling is the entire population is used as a sample. Data collection methods used by researchers were questionnaires and learning outcomes tests. The instruments used in this research are learning outcomes test instruments and emotional intelligence questionnaire instruments. The questionnaire instrument used a Likert scale, while the learning outcomes test is in multiple-choice tests and essays. The students' emotional intelligence scale is based on Goleman's theory. The instrument is validated before use. Based on the test results, the instrument used is valid and reliable.

The data analysis used in this study includes descriptive statistical data analysis and inferential statistics. The descriptive analysis presents data with histograms and calculates the mean, standard deviation, maximum value, and minimum value. Before testing the research hypothesis using regression analysis, a statistical test of parametric inference, the requirements 
analysis test, which includes normality test and linearity test, is carried out. Hypothesis testing in this study is simple linear regression.

\section{FINDINGS}

The data in this research consists of an independent variable (i.e., emotional intelligence) and a dependent variable (i.e., student learning outcomes). The emotional intelligence scale has four answer options: strongly agree, agree, disagree, and strongly disagree. From the emotional intelligence data that researchers have distributed, it was found that the average score was 50 with a minimum score of 42 and a maximum score of 58. Student learning data is obtained from the results of the tests given, consisting of 15 points of multiple-choice questions and 5 points of essay problems. The tests found that the average score of student learning outcomes is 75 , with the highest score of 90 and 68.

\section{Normality Test}

Before regression analysis, first test the analysis requirements in the form of residual normality test (estimate error normality test), which is a requirement that must be met before conducting a parametric inference statistical analysis. A good model is if it has a residual value that is normally distributed. In this study, the residual normality test method was used using the one-sample Kolmogorov Smirnov test. The criteria for normality testing are if the significance value is $>0.05$, then Ho is accepted. Namely, the residuals are normally distributed and vice versa if the significance value is $<0.05$, then Ho is rejected. Namely, the residuals are not normally distributed. The summary of the results of the normality test can be seen in Table 1.

Table 1. Normality Test Results

\begin{tabular}{cccc}
\hline Variable & Asymp-sig. (2-tailed) & $\begin{array}{c}\text { Level of } \\
\text { signification }\end{array}$ & Decision \\
\hline $\begin{array}{c}\text { Emotional } \\
\text { Intelligence }\end{array}$ & 0.295 & 0.05 & $\begin{array}{c}\text { Normally } \\
\text { distributed }\end{array}$ \\
\hline Learning Outcomes & 0.389 & 0.05 & $\begin{array}{c}\text { Normally } \\
\text { distributed }\end{array}$ \\
\hline
\end{tabular}

Based on Table 1, the significance value of the emotional intelligence variable and learning outcomes variable was more significant than 0.05 . It can be concluded that the emotional intelligence variable, the learning outcome variable, was normally distributed.

\section{Linearity Test}

Linearity testing using SPSS. This linearity test is to test whether the dependent variable and the independent variable are linear or not. A good regression model is a regression model with independent variables and linear dependent variables. The test results showed a significance value greater than 0.05 , namely 0.851 . This data shows that the independent variable and the dependent variable in this study are linear.

\section{Hypothesis Test}

The research hypothesis is that there is an effect of emotional intelligence on student learning outcomes in Islamic Education subjects. The research hypothesis was tested using simple linear regression. The test results are presented in Table 2.

Table 2. Regression Results

\begin{tabular}{cc}
\hline Independent Variable & Regression Coefficient \\
\hline Constant & 1.264 \\
\hline Emotional Intelligence & 0.095 \\
\hline
\end{tabular}


From the table above, it can be seen that the value of the constant for the emotional intelligence variable is 1.264 , while the results of the regression coefficient for the emotional intelligence variable are 0.095 . Therefore, a regression model can be made with the following formula.

$$
Y=1.264+0.095 X_{2}
$$

The significance of the regression equation can be implied that the regression coefficient value of the emotional intelligence variable is 0.095 , which means that each addition of one point to the emotional intelligence variable will increase learning outcomes by 0.095 times and the value of the constant of 1.264 means that if the value of X1 $=0$ or the emotional intelligence variable does not exist, then the value of learning outcomes is 1.264. The interpretation of the regression equation above shows that the regression coefficient for the emotional intelligence variable has a positive sign of 0.095 which means that emotional intelligence is in line with the learning outcome variable. Therefore, this emotional intelligence variable has a positive effect on learning outcomes. For more details, this hypothesis testing uses the t-test to find out whether the hypothesis is accepted or not.

\section{T-Test}

This t-test was conducted to determine whether there was an influence between emotional intelligence variables on learning outcomes variables. From the results of data processing, obtained t-count of 2,949 with a significance of 0.005 . This finding indicates that the hypothesis is accepted that there is an effect of emotional intelligence on learning outcomes.

\section{Coefficient of Determination}

The coefficient of determination test is used to measure the accuracy of the analytical model made. The coefficient of determination helps measure the contribution of the independent variables studied to the dependent variable.

Based on the test results, R2 value of 0.214 . This value means that the emotional intelligence variable influences learning outcomes by $21.40 \%$, and $78.60 \%$ are influenced by other variables outside the model included in this study. Therefore, the coefficient of determination test is obtained from the results of regression calculations, then the coefficient of determination is 0.214 or $\mathrm{R}^{2} \times 100 \%$ the result is $21.40 \%$.

\section{DISCUSSION}

The research findings suggest an influence of emotional intelligence on student learning outcomes in Islamic Education subjects. The magnitude of the direct influence of Emotional Intelligence on learning outcomes is $21.40 \%$, and other factors outside of emotional intelligence influence $78.60 \%$.

Based on the calculations above, the results of the study are following the submission of the research hypothesis that states that there is an effect of Emotional Intelligence on student learning outcomes. However, the effect is not too significant, only $21.40 \%$. Although the influence of emotional intelligence on learning outcomes is only $21.40 \%$, there is a positive correlation. According to Goleman (2015), emotional intelligence is a person's ability to regulate his emotional life with intelligence; maintain emotional harmony and expression through selfawareness skills, self-control, self-motivation, empathy, and social skills. Goleman (2015) argues that emotional intelligence is a person's more ability to motivate oneself, be resilient in the face of failure, control emotions and delay gratification, and regulate one's mental state. 
In Goleman's opinion above, it can be concluded that emotional intelligence is related to student learning outcomes. Emotionally intelligent students can motivate themselves well and control their emotions to focus their attention on the lesson. Students need to pay much attention to understanding complex materials, usually involving systematically arranged abstract ideas, and require a high degree of mental activity. Hence, to improve and maintain student learning outcomes, one of which is to increase students' emotional intelligence. To increase Emotional Intelligence must also be supported by Intellectual Quotient. In the student learning process, these two bits of intelligence are indispensable. The intellectual quotient functions appropriately without the participation of emotional appreciation of the subjects delivered. However, these two bits of intelligence complement each other. The balance of Intellectual Quotient and Emotional Intelligence is the key to student success in understanding the subject matter. A person with well-developed emotional skills means that he is likely to succeed in life and has the motivation to excel (Triatna \& Risma, 2008). Meanwhile, individuals who cannot control their emotional life will experience inner struggles that damage their ability to focus on their tasks.

Emotional intelligence needs to be honed from an early age because emotional intelligence is one of the axes of individual success in various aspects of life. Children's ability to develop emotional intelligence is positively correlated with academic, social, and mental health success. Children who have high emotional intelligence are identical to happy, highly motivated, and able to survive in various situations stressful conditions faced (Mashar, 2011).

Emotional intelligence is an essential factor in developing children's intellectual abilities; this is in line with Semiawan's view that stimulation intelligible property is strongly influenced by emotional involvement, that emotion also determines the intellectual development of children gradually (Semiawan in Uno, 2012). Furthermore, according to Devies in Darmadi (2017), emotional intelligence is a person's ability to control himself and others and use that information to guide one's thought processes and behavior. Students who have a high ability to manage emotions tend to be very productive and effective in whatever they face. The ability to recognize other people's emotions and build good relationships with the social environment makes many choices for students to learn how to behave and think. Students with high emotional intelligence will focus on understanding the subject matter, motivate themselves to move forward, be optimistic in facing difficulties, and have exemplary learning achievements (Islami et al., 2020). Students who have low self-confidence and high anxiety have low emotional intelligence to affects their academic achievement (Ebinagbome \& Nizam, 2016).

People with high emotional intelligence understand themselves, care about others, and balance emotions with their intelligence to produce harmony. This research concurs with the research that has been conducted by Sulistianingsih (2016). The results of that study are (1) There is a significant effect of emotional intelligence and motivation together on the ability to think critically in mathematics; (2) There is a significant effect of emotional intelligence on the ability to think critically in mathematics; and (3) There is a significant effect of motivation on the ability to think critically in mathematics (Sulistianingsih, 2016). In addition, the research results of Utami et al. also found an influence of emotional intelligence on students' biology learning outcomes by $39.4 \%$ (Utami et al., 2020).

\section{CONCLUSION}

This study concluded that there was a significant effect of emotional intelligence on student learning outcomes in Islamic Education subjects. Children's ability to develop emotional intelligence is positively correlated with academic, social, and mental health success. Therefore, emotional intelligence needs to be honed from an early age because emotional intelligence is one of the axes of individual success in various aspects of life. 


\section{REFERENCES}

Alvarez, N., Martos, M., \& Extremera, N. (2020). A Meta-Analysis of the Relationship Between Emotional Intelligence and Academic Performance in Secondary Education: A MultiStream Comparison. Frontieers in Psychology, 11(1517), 1-11. https://doi.org/10.3389/fpsyg.2020.01517

Darmadi, (2017). Pengembangan Model Metode Pembelajaran dalam Dinamika Belajar Siswa. Yogyakarta: Deepublish.

Daud, F. (2012). Pengaruh Kecerdasan Emosional (EQ) Dan Motivasi Belajar Terhadap Hasil Belajar Biologi Siswa SMA 3 Negeri Kota Palopo. Jurnal Pendidikan Dan Pembelajaran Universitas Negeri Malang, 19(2), 243-255.

Dewi, S. (2020). Pengaruh Kecerdasan Emosional Terhadap Hasil Belajar Matematika SMAN Di Jakarta Timur. Fokus Ekonomi, 01(1), 86-97. http://stiepena.ac.id/wpcontent/uploads/2012/11/pena-fokus-vol-4-no-2-40-45.pdf

Ebinagbome, M. E., \& Nizam, D. I. (2016). The Impact of Emotional Intelligence on Student's Academic Performance: International Journal of Accounting and Business Management, 4(1), 10-18. https://doi.org/10.24924/ijabm/2016.04/v4.iss1/10.18

Febrianti, L., \& Rachmawati, L. (2018). Pengaruh Kecerdasan Emosional Dan Disiplin Belajar Terhadap Hasil Belajar Siswa Di SMA Negeri 3 Nganjuk. Jumal Pendidikan Ekonomi (JUPE), 6(2), 69-75.

Gafur, A. (2012). Desain Pembelajaran. Penerbit Ombak: Yogyakarta

Goleman, D. (2015). Emotional Intelegence, Kecerdasan mosional "Mengapa EI Lebih Penting dari IQ". Terjemahan oleh T Hermaya. Jakarta: Gramedia Pustaka Utama Pendidikan Nasional.

Islami, A., Putra, A., Deswita, R., Rusliah, N., Matematika, S. P., Sumur, D., Kecamatan, J., Bukit, P., \& Penuh, S. (2020). The effect of emotional intelligence on mathematical concepts understanding of junior high school students. MaPan: Jurnal Matematika Dan Pembelajaran, $8(1), 61-75$.

Kurnia, H., \& Wahono, J. (2021). Pengaruh Kecerdasan Emosional Terhadap Prestasi Belajar Pendidikan Pancasila Dan Kewarganegaraan Siswa SMA Negeri 5 Yogyakarta. Academy of Education Journal, 12(1), 82-97. https://doi.org/10.47200/aoej.v12i1.431

Mashar, R. (2011). Emosi Anak Usia Dini dan Strategi Pengembangannya. Jakarta:Kencana

Purnaningtyas, A., Sendratasik, J., Semarang, U. N., Suharto, S., Sendratasik, J., \& Semarang, U. N. (2010). Pengaruh Kecerdasan Emosi Terhadap Prestasi Belajar Siswa Mata Pelajaran Seni Budaya Smp. Harmonia Journal of Arts Research and Education, 10(1). https://doi.org/10.15294/harmonia.v10i1.56

Rahmawati, K. P., Djaja, S., \& Suyadi, B. (2017). Pengaruh Minat Belajar Dan Kecerdasan 
Emosional Terhadap Prestasi Belajar Siswa Kelas XI IPS SMA Negeri 1 Prajekan

Kabupaten Bondowoso Tahun Ajaran 2016 / 2017. Jurnal Pendidikan Ekonomi: Jurnal Ilmiah Ilmu Pendidikan, Ilmu Ekonomi , Dan Ilmu Sosial, 11(2), 61-68. https://doi.org/10.19184/jpe.v11i2.6448

Sudjana, N. (2014). Penilaian Hasil Proses Belajar Mengajar. Bandung: PT. Remaja Rosdakarya.

Sulastri, T., Suryana, Y., \& Hidayat, S. (2021). Pengaruh Kecerdasan Emosional terhadap Prestasi Belajar Matematika Siswa Kelas V Sekolah Dasar Negeri 1 Manonjaya. Pedadidaktika: Jurnal Ilmiah Pendidikan Guru Sekolah Dasar, 8(1), 156-165.

Sulistianingsih, P. (2016). Pengaruh Kecerdasan Emosional Dan Motivasi Belajar Terhadap Kemampuan Berpikir Kritis Matematika. JKPM, 02(01), 129-139.

Triatna, C., \& Risma. (2008). EQ Power Panduan Meningkatkan Kecerdasan Emosional.. Bandung: Citra Praya

Uno, B. H.(2012). Perencanaan Pembelajaran. Jakarta: Bumi Aksara.

Utami, S. A., Damayanti, E., \& Ismail, W. (2020). Pengaruh Kecerdasan Emosional Terhadap Hasil Belajar Biologi Peserta Didik. Psikoislamedia: Jurnal Psikologi, 05(01), 1-13. https://jurnal.ar-raniry.ac.id/index.php/Psikoislam/article/view/6138 